\title{
Social Skills Inventory for Caregivers of Elderly Family Members (SSI-CE): Relations with Indicators of Psycholgical Wellbeing
}

\author{
Francine Náthalie Ferraresi Rodrigues Queluz ${ }^{*}, 1$ \\ Orcid.org/0000-0002-8869-6879 \\ Elizabeth Joan Barham ${ }^{2}$ \\ Orcid.org/0000-0002-7270-4918 \\ Zilda Aparecida Pereira Del Prette ${ }^{2}$ \\ Orcid.org/0000-0002-0130-2911 \\ Acácia Aparecida Angeli dos Santos ${ }^{1}$ \\ Orcid.org/0000-0002-8599-7465
}

${ }^{1}$ Universidade de São Francisco, Campinas, SP, Brasil ${ }^{2}$ Universidade Federal de São Carlos, São Carlos, SP, Brasil

\begin{abstract}
The experience of caring for a dependent elderly person often involves feelings of stress and burden. In this context, a well-developed repertoire of social skills can improve interpersonal relationships, resulting in better psychological wellbeing. The Social Skills Inventory for Caregivers of the Elderly Family Members (SSI-CE) was developed to evaluate interventions that aim to improve caregivers' social skills. Evidence of the internal validity of the SSI-CE is positive. The objective of this study was to analyze evidence of construct validity by verifying the convergent validity of the SSI-CE, based on relations with other constructs, namely: quality of life, quality of the dyadic relationship, perceptions of burden and depressive symptoms. A total of 205 family caregivers of the elderly, with a mean age of 51 years $(S D=14)$, with different socioeconomic and educational levels, completed the SSI-CE, the Dyadic Relationship Scale (with two subscales: Positive Interaction and Conflicts), the Beck Depression Inventory and Novelli's Quality of Life Scale. The SSI-CE was positively correlated with quality of life and with the Positive Interactions subscale and negatively correlated with burden, depressive symptoms, conflicts. The results support the construct validity of the SSI-CE, but other evidence of validity is still needed.
\end{abstract}

Keyword: Caregivers, elderly, social skills, psychological assessment, quality of life.

Mailing address: Rua Lucio Pereira Peixoto, 95, ap. 57, Jardim Chapadão. CEP 13070-028 - Campinas - SP. E-mail: francine.queluz@gmail.com

Apoio financeiro: Fundação de Amparo à Pesquisa do Estado de São Paulo - FAPESP (2012/00907-3) (2015/20548-6), Bolsa Estágio de Pesquisa no Exterior - BEPE FAPESP (2014/25158-9) e da Coordenação de Aperfeiçoamento de Pessoal de Nível Superior - CAPES.

Nota do autor: A obtenção do IHS-CI será feita por meio de contato com os autores. 


\section{Inventário de Habilidades Sociais para Cuidadores Familiares de Idosos (IHS-CI): Relações com Indicadores de Bem-Estar Psicológico}

\section{Resumo}

Exercer a tarefa de cuidar de um idoso dependente pode gerar estresse e sobrecarga. Neste contexto, um repertório bem desenvolvido em habilidades sociais pode melhorar as relações interpessoais, tendo como consequência melhor bem-estar psicológico. O Inventário de Habilidades Sociais para Cuidadores Familiares de Idosos (IHS-CI) foi elaborado para avaliar intervenções que visem aprimorar às habilidades sociais de cuidadores. Evidências da validade interna do IHS-CI são positivas. No presente estudo, o objetivo foi analisar evidências de validade de construto mediante a verificação de validade convergente do IHS-CI, baseada nas relações com outras variáveis: qualidade de vida, qualidade da relação diádica, percepções de sobrecarga e sintomas depressivos. Participaram do estudo 205 cuidadores familiares de idosos, com idade média de 51 anos $(D P=14)$, com diferentes níveis socioeconômicos e de escolaridade, que responderam ao IHS-CI, à Dyadic Relationship Scale (com duas subescalas, Conflitos e Interação Positiva), ao Inventário de Depressão de Beck e à Escala de Qualidade de Vida de Novelli. O IHS-CI se mostrou positivamente correlacionado com qualidade de vida e com a subescala de Interação Positiva e negativamente com sobrecarga, sintomas depressivos e conflitos. Estas evidências apontam para a validade de construto do IHS-CI, mas evidências adicionais de validade ainda são necessárias.

Palavras-chave: Cuidadores, idosos, habilidades sociais, avaliação psicológica, qualidade de vida.

\section{Inventario de Habilidades Sociales para Cuidadores Familiares de Adultos Mayores (IHS-Cl): Relaciones con Indicadores de Bienestar Psicológico}

\section{Resumen}

Ejercer la tarea de cuidar a un mayor dependiente puede crear estrés y sobrecarga. En este contexto, un repertorio bien desarrollado de habilidades sociales puede mejorar las relaciones interpersonales, lo que resulta mejor bienestar psicológico. El Inventario de Habilidades Sociales para los cuidadores de adultos mayores (IHS-CI) se diseñó para evaluar las intervenciones destinadas a mejorar las habilidades sociales de los cuidadores. Evidencias de la validez interna IHS-CI son positivas. El objetivo de este estudio fue analizar evidencia de validez de constructo comprobando su validez convergente para o IHS-CI, en base a las relaciones con otras variables, que son: calidad de vida, calidad de la relación diádica, sobrecarga y depresión. El estudio incluyó 205 cuidadores de personas mayores de la familia con una edad media de 51 años $(D E=14)$, con diferentes niveles socioeconómicos y de educación que respondieron el IHS-CI, Dyadic Relationship Scale (con las subescalas Interacción Positiva y Conflictos), Inventario de Depresión de Beck y la Escala de calidad de vida de Novelli. El IHS-CI presentó una correlación positiva con la calidad de vida y con la subescala Interacción Positiva y negativa con sobrecarga, depresión y conflicto. Estas evidencias apuntan para la validez de constructo del IHS-IC, pero aún se necesitan nuevas pruebas de validez.

Palabras clave: Cuidadores, personas mayores, habilidades sociales, evaluación psicológica, calidad de vida.

One of the results of population aging is a dramatic increase in the number of elderly people who have chronic degenerative diseases, leading to a higher demand for long-term care 
for frail seniors. In Brazil, those who care for the elderly are usually family members, particularly wives or middle-aged daughters, who have a low income and low educational level (Gratão et al., 2013; Loureiro \& Fernandes, 2015). When they undertake the responsibility of caring for a dependent elderly person, caregivers must adapt to new situations and demands, which can be of a physical, cognitive or psychological nature (Arakaki, Tsubaki, Caramelli, Nitrini, \& Novelli, 2012; Wang, Robinson, \& Carter-Harris, 2014). Among elderly people, the greater their age, the greater the probability that they will suffer from various, concurrent health problems that limit their independence, resulting in significant caregiving demands (Lorenzini, 2014).

Researchers have demonstrated that, as time passes and an elderly person's level of dependency increases, the escalating demands caregivers face can result in feelings of burden and stress, which may lead to depression, directly influencing their quality of life (Barham, Pinto, Andrade, Lorenzini, \& Ferreira, 2015; Li, Cooper, Bradley, Shulman, \& Ryan, 2012; Lin, Chen, \& Li, 2013; Neri et al., 2012; Pereira \& Soares, 2015; Pinto, Barham, \& Del Prette, 2016). Moreover, caregiving duties are frequently undertaken by one person, alone, resulting in a heavier impact than when caregiving is divided among various family members (Pereira \& Soares, 2015).

The tasks that arise in the context of caring for an elderly relative can lead caregivers to have difficulties in maintaining contact with those who are part of their social support group, which increases the difficulty of requesting and obtaining help (Pinto, Barham, \& Albuquerque, 2013; Pinto et al., 2016; Segrin, McNelis, \& Swiatkowski, 2016). Individuals who have a wide range of social skills and who are able to use these skills in their everyday lives, however, will usually talk with all those involved in the situation to find ways to deal with demands, so as to take everyone's needs into account, including the needs of the elderly person, other relatives, and the caregivers themselves (Pinto et al., 2016).

Segrin et al. (2016) proposed a model of psychosocial vulnerability that stems from social skills deficits. According to these researchers, individuals with fewer social skills are more vulnerable to psychological distress, given that they receive less social support and thus have little benefit of its protective effects. For caregivers, the protective effects of receiving more or better quality social support can result in lower perceptions of burden, as well as having free time for self-care and other valued activities.

To get help from others (family members, friends, and professionals), caregivers must be able to use a complex set of social skills. Those who can use these skills in a socially proficient manner are able to gain and maintain the participation and support of individuals who belong to their informal and formal social circles, increasing the amount of help they receive (Del Prette \& Del Prette, 2013; Segrin et al., 2016). Successfully using these abilities improves their resilience and effectiveness as caregivers (Pinto \& Barham, 2014; Pinto et al., 2016, Segrin et al., 2016). As such, having the ability to interact with others in a socially proficient manner while caring for a dependent elderly person can be an essential factor in minimizing caregivers' dayto-day problems. For example, caregivers need to be able to discuss issues with their elderly relative so that both can agree on what to do, to renegotiate each family member's duties when their elderly relative's routines change, to be good at expressing positive feelings towards all those involved in the situation, etc.

\section{Social Skills}

According to Del Prette and Del Prette (2013), social skills involve behaviors that contribute to successfully completing tasks that involve interactions with others (social tasks), while also maintaining or improving the quality of relationships with those involved. Social skills are organized in behavioral classes, including: expressing positive emotions, controlling aggressive behaviors, showing empathy, expressing opinions, being polite, explaining ideas or providing information, working cooperatively, expressing ideas in public situations (or meeting new people), and being assertive (Del Prette \& Del Prette, 2013). In the field of social skills, the 
concept of social competence is also important. Social competence refers to judgements about the effectiveness of a given person's social behavior within a certain culture or context, based on both instrumental and ethical criteria. These criteria take into account not only the individual's immediate interests, but also the mid-term and long-term quality of the relationships among the people who comprise his or her social group and the possibility of also meeting the needs of each group member (Del Prette \& Del Prette, 2001, 2010, 2013). Thus, social skills are contextual in nature, and as such, situational factors directly influence how a given person's behavior will be judged by others. This leads to the observation that people can be evaluated as being socially competent in some social contexts, but may not be evaluated positively in other contexts. Thus, someone who cares for an elderly relative might demonstrate high social competence when caring for this family member (discerning when and how to use social skills to successfully perform caregiving tasks, while also maintaining a good relationship with others), but perhaps not in a marital context, or vice-versa.

To interact with others in a socially competent manner requires recognizing and responding to the needs and interests of the others. When a person is unwilling to deal with others' needs, is unaware of their needs, or does not have the resources or abilities that are required to respond to their needs, his or her performance will be less socially competent. It is also important to realize that there are differences in the interpersonal demands that are present in different social contexts. As such, caregivers need social interaction skills to accomplish activities with their elderly relative that are not the same as those they use when dealing with their professional associates, which are also different from the social skills that are important when doing things with friends, or with their spouses, and so on. Even when interactions in each setting involve a common element (such as asking for help), contextual differences affect the manner in which their social skills should be used, given that the relationships are different. For example, asking a paid cleaning worker for help with housework is different from requesting the same help from one's spouse.

In addition to contextual issues, it is also important to consider the implications of research findings that indicate that social skills are acquired over the course of one's life, through three basic learning processes: direct instruction, consequences that follow one's actions, and observing others (Del Prette \& Del Prette, 2001, $2010,2013)$. Based on the premise that social skills are learned, this implies that people can overcome social skills deficits, for example, if they receive social skills training, by participating in situations where the conditions for learning social skills are restructured (Barham et al., 2015; Del Prette \& Del Prette, 2001, 2013; Segrin et al., 2016; Robinson, 1988, 1990; Robinson $\&$ Yates, 1994). Studies conducted with various target populations have shown that people who have a broader range of social skills tend to report better quality of life, higher perceptions of social support, and fewer depressive symptoms (Braz, Del Prette, \& Del Prette, 2011; Carneiro, Falcone, Clark, Del Prette, \& Del Prette, 2007). In the case of caregivers, Franzmann, Krause, Haberstroh, and Pantel (2014), Muela, Torres, and Peláez (2001), Pinto and Barham (2014) and Robinson (1990) conducted studies to investigate the relationships among caregivers' social skills and their perceptions of social support, self-esteem, stress, burden and relationship quality. The findings reveal that social skills have a positive influence on caregivers' wellbeing, indicating that a broader array of social skills is positively associated with greater social support, higher self-esteem and better relationship quality. Furthermore, stronger social skills are negatively associated with perceptions of stress, burden and conflicts.

Considering these findings, and bearing in mind the contextual nature of social skills, we suggest that it would be important to construct an instrument for assessing social skills of those who care for elderly family members. Using such an instrument, interventions to promote improvements in caregivers' social skills could be evaluated, as a means of identifying effective ways of increasing caregivers' quality of life. 
Based on a systematic review of studies about instruments for evaluating social skills, conducted by Bender and Calvetti (2015), it appears that such a scale has not yet been developed. Subsequently, based on her own review of the Brazilian and foreign literature, Pinto (2016) created the Social Skills Inventory for Caregivers of Elderly Family Members (SSI-CE), which is the instrument we describe in the present study.

Some of the SSI-CE's psychometric properties have already been described (Queluz, Barham, Del Prette, Fontaine, \& Olaz, 2017). In their report of their first study, the authors describe the procedures used to construct the instrument. Initially, five specialists examined the semantic and content validity of the 37 original items, which led to alterations in the wording of several items and the removal of six items. Subsequently, 20 caregivers completed the instrument, so the researchers could verify their comprehension of each item as well as of the instructions, which led to further alterations. In the second study, the internal structure of the instrument was examined (via exploratory factor analysis) and then the reliability of each factor was determined (reporting values for Cronbach's alpha). The best solution for the internal structure was an instrument comprised of 24 items, represented by three factors: Emotional Expressiveness, Assertive Communication, and Information Seeking. The first factor, Emotional Expressiveness, indicates a caregiver's ability to express affection for others, especially the dependent elderly person. The second factor, Assertive Communication, refers to the caregiver's skills in handling problematic interactions that involve conflicts, particularly when there is a risk of the other party responding negatively. The third factor, Information Seeking, deals with the caregiver's capacity to acquire information that is useful in understanding how to care for an elderly person as well as his or her ability to share these ideas with others who are involved in the caregiving situation. Analyses of the three-factor SSI-CE solution revealed excellent internal reliability for the instrument as a whole and satisfactory $(0.60$ $<\alpha)$ to very good $(\alpha<0.90)$ reliability for each of the factors. However, additional evidence is still needed, to verify other aspects of the validity of this instrument. In the present study, evidence of convergent validity was used to further examine the construct validity of the HIS-CE, by examining associations between people's social skills and other variables, namely quality of life, dyadic relationship quality (which has two subscales: Positive Interaction and Conflicts), burden and depressive symptoms (Braz et al., 2011; Carneiro \& Falcone, 2013; Carneiro et al., 2007; Franzmann et al., 2014; Muela et al., 2001; Pinto \& Barham, 2014; Robinson, 1990).

As such, we established the following hypotheses, based on prior research (Barham et al., 2015; Muela et al., 2001; Pinto \& Barham, 2014; Pinto et al., 2016; Robinson, 1990): (a) SSI-EC scores will have a negative relationship with measures of caregiver burden, of conflicts in the relationship between the caregiver and the elderly care recipient, and of depressive symptoms; and (b) SSI-EC scores will have a positive relationship with measures of positive interactions between the caregiver and the elderly care recipient and of quality of life.

\section{Method}

\section{Participants}

We interviewed 205 caregivers ( 180 women and 25 men) between the ages of 18 and 87 years $(M=51, S D=14)$, who assisted an elderly family member. On average, they had been caregivers for 5 years $(S D=4.7)$. With respect to the participants' marital status, 59 were single, 105 were married (or in a common-law relationship), 27 were separated, and 14 were widowed. They also had varying educational levels, including caregivers who were illiterate (19), who had completed only an elementary school education (36), intermediate school (21), high school (53) or a university degree (76). There were also differences in their economic conditions, meeting the criteria for classification in the following social classes: A (16), B (67), C (98) and D (24). Their degree of kinship with their elderly family member was as follows: adult children (138), grandchildren (21), spouses (19), daughters-/sons-in-law (15), siblings (9) 
and other relationships (3). The participants resided in cities of various sizes in the interior of the state of São Paulo: small (34), medium (118) and large (53) cities. Given that the majority of the caregivers could not leave their elderly relative alone at home, the interviews were conducted during home visits, or at the location of the caregiver's choice, as long as there would be a room with privacy, to conduct the interview.

We recruited the caregivers via referrals made by: (a) employees at public healthcare agencies that offer homecare services, in the cities of São Carlos and Campinas, (b) workers at the São Carlos Federal University Healthcare Unit, (c) other participants, or (d) people known to the researchers in the cities of São Paulo and Itapira. All caregivers lived in the state of São Paulo, Brazil. We used the following inclusion criteria: potential participants had to be at least 18 years old and relatives of the elderly person for whom they were caring. Formal or paid caregivers were not included, because a number of the consequences of caregiving are significantly different for family caregivers and formal caregivers (Camargo, 2010).

\section{Instruments}

Sociodemographic Questionnaire. We prepared a brief questionnaire to ascertain the participants' sociodemographic characteristics (sex, age, education, marital status, etc.), to describe the sample.

Brazilian Socioeconomic Classification Criteria (Associação Brasileira de Empresas de Pesquisa [ABEP], 2013): We used the "criteria Brazil" classification system to assess the socioeconomic status of the participants' families. This instrument is used to evaluate the respondent's purchasing power on the basis of the number of durable consumer goods they have acquired, employment of in-home workers, and the household head's educational level, subdividing the population into seven classes, from highest to lowest: A1, A2, B1, B2, C1, C2, D and $\mathrm{E}$.

Social Skills Inventory for Caregivers of Elderly Family Members (SSI-CE; Queluz et al., 2017): The SSI-CE is a self-report questionnaire consisting of 24 items and 3 factors: Emotional Expressiveness (10 items, $\alpha=0.87$ ), Assertive Communication (10 items, $\alpha=0.79$ ) and Information Seeking (4 items, $\alpha=0.60$ ). Cronbach's alpha for the total score was 0.89 . The first and second factors produce scores that can vary from 10 to 40; the third factor produces a score between 4 and 12. The sum of the scores of all three factors can vary between 24 and 96 . In order to answer the SSI-CE questionnaire, examinees must specify the frequency with which they emit the behavior described in each item: "never" (1 point), "occasionally" ( 2 points), "frequently" (3 points) or "always" (4 points). The higher the score, the better the social skills repertoire of the examinee.

Dyadic Relationship Scale (DRS): The scale we used is a Portuguese-language version of Sebern and Whitlatch's Dyadic Relationship Scale (2007), which is used to assess the quality of the relationship between the caregiver and the elderly person, considering negative and positive aspects. There is a specific version for each member of the dyad. The caregiver's version consists of 11 statements relating to the quality of the dyadic relationship and the transformations resulting from the caregiving situation. For each statement, there are four possible responses: 1 (fully disagree), 2 (disagree), 3 (agree) or 4 (fully agree). The DRS is subdivided into two subscales; one is used to rate "Positive Interactions" between the caregiver and the elderly person, and the other is used to rate "Conflicts." The higher the scores on each subscale, the higher the level of positive interactions (Subscale 1) or of conflicts (Subscale 2) in the relationship. The internal consistency of the instrument was $\alpha=$ .85 for the "Positive Interaction" subscale, and $\alpha$ $=.89$ for the "Conflicts" subscale.The DRS was translated by Thomazatti and Barham (2010) in a study they conducted to assess its semantic and content validity, within the Brazilian context.

Beck Depression Inventory (BDI): The Beck Depression Inventory (Beck, Rush, Shaw, \& Emery, 1979) is used to detect symptoms of depression. It is a self-report survey consisting of 21 questions, each of which includes four possible responses that range from low ( 0 points) 
to high ( 3 points) severity of depressive symptoms. Respondents mark the response that best describes how they have been feeling during the past week. The final score is determined by the sum of the scores of the marked responses. Scores between 0 and 11 points indicate minimal depression; between 12 and 19, mild depression; between 20 and 35, moderate depression; and over 36, severe depression. In the Portugueselanguage reference study (Gorenstein, \& Andrade, 1998), the authors reported high internal consistency $(\alpha=0.81)$. As characterized at the time, the BDI exhibited both factor validity and discriminant validity, given that BDI scores distinguished depressed people from both anxious individuals and persons lacking emotional problems (Shafer, 2006).

Zarit Burden Interview (ZBI). We quantified perceptions of burden associated with the caregiving role using the ZBI, which was adapted for use in Brazil by Taub, Andreoli and Bertolucci (2004). The ZBI is a 22-item questionnaire that is used to measure perceptions of burden among caregivers of elderly family members. This instrument is comprised of four factors: Caregiving Impact, Interpersonal Relationship, Caregiving Expectations, and Perceptions of Self-efficacy. The rating-scale for each item includes the following options: 0 (never), 1 (rarely), 2 (at times), 3 (very frequently) and 4 (always). Thus, the final score can vary between 0 and 88 . Using the respondent's total score on the Brazilian version of the ZBI, the severity of the examinee's perceptions of burden can be classified in the following manner: less than 21 points, minimal or no burden; 21 to 40 points, mild to moderate burden; 41 to 60 points, moderate to severe burden; 61 to 88 points, severe burden. Although the instrument consists of four factors, it can also be considered in a one-dimensional manner, exhibiting overall internal consistency of $\alpha=0.87$ (Scazufca, 2002). We were unable to locate published studies reporting the internal consistency of the four-factor scoring system, for the Brazilian population. Scazufca (2002) also investigated the construct validity of the ZBI, indicating that it was positively associated with both emotional distress $(r=.37, p=.001)$ and behavioral and mood-related problems in caregivers $(r=.54, p=.001)$.

Quality of Life Scale. Validated for use in Brazil by Novelli (2006), the cross-cultural adaptation of the two versions of this instrument are used to assess perceptions of quality of life among elderly people (including those with mild to moderate levels of Alzheimer's disease) and of their caregivers. We used the caregiver version of this scale, which consists of 13 items (e.g., health, marriage, housing, etc.). Respondents evaluate their current situation using a four-point scale ranging from 1 (poor) to 4 (excellent), resulting in a total score that varies between 13 and 52. The higher the score, the higher the respondent's perceived quality of life. The Brazilian adaptation of this scale consists of a single dimension and exhibits high internal consistency in terms of Cronbach's alpha $(\alpha=.86)$. Novelli also reported evidence for the construct validity for this instrument; scores on this quality of life scale were negatively correlated with depressive symptoms $(r=-.59, p<.01)$ and positively correlated with scores on a second quality of life scale $(r=.81, p<.01)$.

\section{Data Collection Procedure}

Initially, we contacted Health Department officials and Homecare Services agency directors in the cities of São Carlos and Campinas, who provided contact information about caregivers who met the inclusion criteria. These caregivers were contacted by telephone, to invite them to participate in the study. When the caregiver agreed to participate, we scheduled an interview in the location of their choice (their home or a neighborhood healthcare agency), as long as it would be possible to guarantee confidentiality and privacy. The same procedure was followed in the case of caregivers who were referred to us by acquaintances. Before initiating the interview with each participant, an informed consent form was read aloud and all of the caregiver's questions were answered.

\section{Data Analysis Procedure}

To verify whether the distribution of ob- 
served scores for each instrument was significantly different from a normal distribution, we calculated the mean, standard deviation, minimum and maximum values, kurtosis and asymmetry values for each variable. Given that data collection was conducted via individual interviews, there were no problems with missing data. Examining the number of modes, the kurtosis and asymmetry values, and the results of the Kolmogorov-Smirnov test (Marôco, 2014; Pasquali, 2015), we observed a normal distribution of scores for each of the variables. Next, we examined Pearson correlation coefficients to check for relationships among the variables. In the present study, we adopted the criteria established by Levin and Fox (2004) to evaluate the magnitude of the correlations: weak, $r$ $<0.30$; moderate, $.30<r<.59$; strong, $.60<r$ $<.90$. The data were analyzed using IBM SPSS Statistics 20 software.

Table 1

\section{Ethical Procedures}

This project was approved by the Ethics Committee of the Federal University of São Carlos (reference number 144.507/2012). All study procedures were in accordance with the Declaration of Helsinki. Prior to signing the informed consent form, all of the caregivers were informed as to their rights, the objectives of the study and the activities entailed in participating in the study.

\section{Results}

\section{Convergent Evidence of Construct Validity}

We examined the magnitude of the correlations between the SSI-CE factors and the other instruments, namely the Dyadic Relationship Scale, the Beck Depression Inventory, and the Zarit Burden Interview and QoL Scale. The results are displayed in Table 1.

Correlations between SSI-CE Scores and Scores for Related Constructs

\begin{tabular}{lcccc}
\hline & \multicolumn{4}{c}{$\begin{array}{c}\text { Social Skills Inventory }- \\
\text { Caregivers of Elderly Family Members }\end{array}$} \\
\hline & $\begin{array}{c}\text { Total } \\
\text { Score }\end{array}$ & $\begin{array}{c}\text { Emotional } \\
\text { Expressiveness }\end{array}$ & $\begin{array}{c}\text { Assertive } \\
\text { Communication }\end{array}$ & $\begin{array}{c}\text { Information } \\
\text { Seeking }\end{array}$ \\
\hline 1. Zarit Burden Interview & & & & \\
Total & $-.43^{* *}$ & $-.45^{* *}$ & $-.29^{* *}$ & $-.28^{* *}$ \\
Impacts of Caregiving & $-.37^{* *}$ & $-.38^{* *}$ & $-.26^{* *}$ & $-.22^{* *}$ \\
Impact on Interpersonal Relationships & $-.51^{* *}$ & $-.55^{* *}$ & $-.31^{* *}$ & $-.38^{* *}$ \\
Caregiving Expectations & $-.29^{* *}$ & $-.32^{* *}$ & $-.19^{* *}$ & $-.16^{*}$ \\
Perceptions of Self-Efficacy & .02 & .07 & -.01 & -.03 \\
2. Dyadic Relationship & & & & $.30^{* *}$ \\
Positive Interaction & $.48^{* *}$ & $.50^{* *}$ & $-.16^{*}$ & $-.30^{* *}$ \\
Conflicts & $-.34^{* *}$ & $-.39^{* *}$ & $.22^{* *}$ & $.25^{* *}$ \\
3. Quality of Life & $.30^{* *}$ & $.27^{* *}$ & $-.20^{* *}$ & $-.25^{* *}$ \\
4. Depression & $-.28^{* *}$ & $-.25^{* *}$ & & \\
\hline
\end{tabular}

${ }^{*} p<.05 ;{ }^{* *} p<.01$

The overall SSI-CE scores correlated positively with the scores of both the positive interaction subscale of the Dyadic Relationship
Scale, and the Quality of Life scale, and correlated negatively with the total score for burden (as well as ZBI factor-scores for caregiving im- 
pact, impact on the relationship, and caregiving expectations), the conflicts subscale of the Dyadic Relationship Scale, and depressive symptoms. With respect to the factors of the SSI-CE, these scores correlated positively with both the Positive Interaction subscale and the Quality of Life Scale and correlated negatively with total burden, caregiving impact, impact on the relationship, caregiving expectations, the conflicts subscale of the Dyadic Relationship Scale, and depressive symptoms. Among the measures evaluated, the ZBI perception of self-efficacy factor was the only factor that did not exhibit a statistically significant correlation with the total scores and with each SSI-CE factor.

\section{Discussion}

In the present study, we analyzed evidence for the construct validity of the SSI-CE, verifying convergent validity based on correlations with other variables, namely: quality of life, dyadic relationship quality (which includes positive interaction and conflicts subscales), perceptions of burden, and depressive symptoms. The results corroborated our preliminary hypotheses, given that scores on the SSI-CE were: (a) positively correlated with scores on measures of quality of life, the subscale for positive interaction of the Dyadic Relationship Scale, and (b) negatively correlated with scores on measures of perceived burden, depressive symptoms, and the conflicts subscale of the Dyadic Relationship Scale. In addition, these results are consistent with findings reported in prior studies (Carneiro et al., 2007; Franzmann et al., 2014; Muela et al., 2001; Pinto \& Barham, 2014; Robinson, 1990).

Perceptions of self-efficacy (from the Zarit Burden Interview) was the only factor that did not display a statistically significant correlation with the HIS-CE scores, a result that may have occurred because this factor is comprised of only two items. One of the two questions for this factor was, "Do you think you could do a better job of caring for your relative?" Although this question relates directly to a caregiver's perception of self-efficacy, it seems less directly related to a sense of burden, per se. In addition, during the interviews, it became apparent that most care- givers believed they were doing their best, given their circumstances, thus explaining the absence of a significant relationship between scores on the Perceptions of Self-efficacy factor and social skills scores.

With respect to the remaining correlations, the strongest relationships were those between the Emotional Expressiveness factor of the SSI$\mathrm{CE}$ and Impact on the Relationship (from the ZBI), and Positive Interaction (from the Dyadic Relationship Scale), all of moderate magnitude. These findings are consistent with results reported in previous studies, suggesting that a better developed array of social skills (especially with respect to communicating positive emotions, represented in the Emotional Expressiveness factor) correlates negatively with perceptions of burden due to an unfavorable Impact on the Relationship, and positively with Positive Interactions between caregivers and their elderly relative (Barham et al., 2015; Pinto \& Barham, 2014; Segrin et al., 2016). Conceptually, this confirms our expectations, as one would presume that those who care for an elderly relative and who have good social skills would be more capable of maintaining positive relationships with the people around them. Caregivers with better social interaction skills may manifest their emotions in a more acceptable manner, perhaps with greater quality and frequency. This, in turn, would lead to a greater likelihood of them receiving help from others than if they were unable to express their feelings, if they were to express themselves in an aggressive manner, or if they could not express their feelings at the right time or to the right people (Pinto et al., 2016; Segrin et al., 2016). Our findings are also consistent with the social skills deficit-related vulnerability model proposed by Segrin et al. (2016). As such, the manner in which caregivers request help can increase or decrease their probability of getting help the next time they are in need, based on their social performance and whether or not they acted in a socially competent manner (Del Prette \& Del Prette, 2013; Pinto et al., 2016).

The correlations observed in this study provide supporting evidence for the construct validity of the SSI-CE (Marôco, 2014; Pasquali, 
1999, 2007, 2015). As expected, and in support of our hypotheses, caregivers' social skills scores were associated with indicators of their mental health (Carneiro \& Falcone, 2013; Carneiro et al., 2007; Del Prette \& Del Prette, 2013; Muela et al., 2001; Pinto \& Barham, 2014; Robinson, 1990).

In a correlational study, it is of fundamental importance to obtain a sample with characteristics that are consistent with the population of interest, as well as to have score variations that follow an approximately normal curve for each variable, as was the case in the present study. Examining our caregiver's sociodemographic characteristics, the number of male participants $(n=25)$ might seem unusually low. Nonetheless, this number is consistent with information reported in the literature, which reveals that, in Brazil, women are predominantly responsible for taking care of dependent, elderly family members, the majority are middle-aged, and most are either the adult children or spouses of the care recipient (Gratão et al., 2013; Loureiro, \& Fernandes, 2015). Although certain caregiver population subgroups can present different mean scores on the instruments, one would still expect similar correlations in each subgroup. Nonetheless, it would be worth investigating potential differences related to sociodemographic factors in a normalization study of the SSI-CE, because differences in the mean scores of subgroups defined by age or sex, for example, would lead to the necessity of establishing sex or age-specific norms for interpreting results for caregivers in each subgroup.

In addition to conducting preliminary validity studies, it is important to consider how the new instrument could be used in practical situations. The SSI-CE would be an important tool for evaluating the effects of interventions to help caregivers expand their social skills, especially with respect to gaining help in a socially competent manner (Del Prette \& Del Prette, 2013; Pinto et al., 2016; Pinto \& Oliveira, 2015; Segrin et al., 2016). Caregivers who receive social skills training could, for instance, improve their abilities to ask other caregivers or healthcare specialists for information concerning an elderly family member's health problems, increase their abilities to let their relative or other family members know how important they are to the caregiver, find ways to discuss a problem without causing anxiety, along with other abilities that can contribute to the ongoing quality of life of everyone involved in the caregiving process.

Along with the caregiver's total score on the SSI-CE, the three factor-scores can also be used to detect shortcomings in each, more specific area. By examining these scores, interventions can be tailored to the needs of caregivers who have a particular difficulty in one of these areas. This would enable professionals to select activities designed to promote skills acquisition with respect to specific abilities in the caregiver's social repertoire.

A validated scale, such as the SSI-CE, that can be used to measure caregivers' social skills would also be an important tool for researchers who are investigating variables that either contribute to greater social competence or that involve potential impacts of social skills, such as social support and stress, that have, so far, received much less attention. Such studies would contribute to establishing an empirical basis for proposing and testing models that capture the processes involved in acquiring and using social skills, given that research on this subject is still scarce (Pinto, 2016). For example, one could test the social-skills deficit vulnerability model (Segrin et al., 2016) with caregivers who assist elderly family members, to determine whether this population suffers greater emotional vulnerability and receives less social support, as a function of social skills deficits.

In closing, further investments are still needed with respect to verifying the validity of the SSI-CE. For example, given that the caregivers evaluated in the present study all resided in the state of São Paulo, Brazil, the instrument should now be tested with caregivers who live in other regions of Brazil, and in the more distant future, in other countries. A confirmatory factor analysis of the SSI-CE is also needed, to verify the exploratory factor analysis reported by Queluz et al. (2017). Two other issues related to instrument validity that also require attention in- 
clude the examination of relationships between SSI-EC scores and sociodemographic variables, and conducting an item-analysis procedure to evaluate the importance of each item.

Based on all these results and considerations, the practical and scientific relevance of the SSI-CE is clearly apparent. In view of the expanding population of dependent elderly people, which leads to an increasing need for caregivers who are willing and able to shoulder responsibilities for assisting them, the possibility of using the SSI-CE could facilitate the work of healthcare specialists, contributing to a greater quality of life among those who care for an elderly relative and, by extension, to the wellbeing of the elderly people who are in their care.

\section{Authors Contributions}

Substantial contribution in the concept and design of the study: Francine Nathalie Ferraresi Rodrigues Queluz e Elizabeth Joan Barham.

Contribution to data collection: Francine Náthalie Ferraresi Rodrigues Queluz.

Contribution to data analysis and interpretation: Francine Náthalie Ferraresi Rodrigues Queluz e Elizabeth Joan Barham.

Contribution to manuscript preparation: Francine Náthalie Ferraresi Rodrigues Queluz,

Contribution to critical revision, adding intelectual content: Elizabeth Joan Barham, Zilda Aparecida Pereira Del Prette e Acácia Aparecida Angeli dos Santos.

\section{Conflicts of interest}

The authors declare that they have no conflict of interest related to the publication of this manuscript.

\section{References}

Arakaki, B. K., Tsubaki, J. N. S., Caramelli, P., Nitrini, R., \& Novelli, M. M. P. C. (2012). Análise do desgaste e da sobrecarga de cuidadores/familiares de idosos com doença de Alzheimer causado pelos sintomas psicológicos e comportamentais. Revista de Terapia Ocupacional da Universidade de São Paulo, 23(2), 113-121.
Associação Brasileira de Empresas de Pesquisa. (2013). Critério de Classificação Econômica Brasil. São Paulo, SP: Author.

Barham, E. J., Pinto, F. N. F. R., Andrade, A. R., Lorenzini, M. F. J., \& Ferreira, C. R. (2015). Fundamentos e estratégias de intervenção para a promoção de saúde mental em cuidadores de idosos. In S. G. Murta, C. Leandro-França, K. B. Santos, \& L. Polejack (Eds.), Prevenção e promoção em saúde mental: Fundamentos, planejamento e estratégias de intervenção (pp. 844-862). Novo Hamburgo, RS: Sinopsys.

Beck, A. T., Rush, A. J., Shaw, B. F., \& Emery, G. (1979). Cognitive Therapy of Depression: A treatment manual. New York: Guilford Press.

Bender, R. S., \& Calvetti, P. U. (2015). Instrumentos de avaliação psicológica em habilidades sociais. Revista de Psicologia da IMED, 7(1), 4-14.

Braz, A. C., Del Prette, Z. A. P., \& Del Prette, A. (2011). Assertive social skills training for the elderly. Behavioral Psychology / Psicología Conductual, 19(2), 373-387.

Camargo, R. C. V. F. (2010). Implicações na saúde mental de cuidadores de idosos: Uma necessidade urgente de apoio formal. SMAD. Revista Eletrônica Saúde Mental Álcool e Drogas, 6(2), 231-254.

Carneiro, R. S., \& Falcone, E. (2013). O desenvolvimento das habilidades sociais em idosos e sua relação na satisfação com a vida. Estudos de Psicologia (Natal), 18(3), 517-526. doi: http://dx.doi. org/10.1590/S1413-294X2013000300012

Carneiro, R. S., Falcone, E., Clark, C., Del Prette, Z. A. P., \& Del Prette, A. (2007). Qualidade de Vida, Apoio Social e Depressão em idosos: Relação com habilidades sociais. Psicologia Reflexão e Crítica, 20(2), 229-237.

Del Prette, Z. A. P., \& Del Prette, A. (2001). Inventário de Habilidades Sociais (IHS-Del Prette): Manual de aplicação, apuração e interpretação. São Paulo, SP: Casa do Psicólogo.

Del Prette, Z. A. P., \& Del Prette, A. (2010). Avaliação de habilidades sociais: Bases conceituais, instrumentos e procedimentos. In A. Del Prette \& Z. A. P Del Prette (Eds.), Psicologia das habilidades sociais: Diversidade teórica e suas implicações (pp. 189-231). Petrópolis, RJ: Vozes.

Del Prette, Z. A. P., \& Del Prette, A. (2013). Social Skills Inventory (SSI-Del-Prette): Characteris- 
tics and studies in Brazil. In F. L. Osório (Ed.), Social anxiety disorders: From theory to practice (pp. 49-62). New York: Nova Science.

Franzmann, J., Krause, K., Haberstroh, J., \& Pantel, J. (2014). Assessment of self-perceived social competencies of caregivers in dementia care: Development and psychometric testing of the SOKO dementia. GeroPsych, 27(2), 67-73.

Gorenstein, C., \& Andrade, L. H. S. G. (1998). Inventario de depressão de Beck: Propriedades psicométricas da versão em português. Revista de Psiquiatria Clínica, 25(5), 245-250.

Gratão, A. C. M., Talmelli, L. F. L. S., Figueiredo, L. C., Rosset, I., Freitas, C. P., \& Rodrigues, R. A. P. (2013). Dependência funcional de idosos e a sobrecarga do cuidador. Revista da Escola de Enfermagem -USP, 47(1),137-44. doi: http:// dx.doi.org/10.1590/S0080-62342013000100017

Levin, J., \& Fox, J. A. (2004). Estatística para ciências humanas. São Paulo, SP: Pearson.

Li, R., Cooper, C., Bradley, J., Shulman, A., \& Ryan, G. (2012). Coping strategies and psychological morbidity in family carers of people with dementia: A systematic review and meta-analysis. Journal of Affective Disorders, 139(1), 1-11.

Lin, W. F., Chen, H. C, \& Li, T. S. (2013). Adult children's caregiver burden and depression: The moderating roles of parent-child relationship satisfaction and feedback from others. Journal of Happiness Studies, 14(2), 673-687.

Lorenzini, M. F. J. (2014). Trabalhadores que cuidam de parentes idosos: Esforços e necessidades na conciliação de responsabilidades profissionais e familiares (Monography, Universidade Federal de São Carlos, SP, Brazil).

Loureiro, L. S. N., \& Fernandes, M. G. M. (2015). Perfil do cuidador familiar de idosos dependentes em convívio domiciliar. Journal of Research: Fundamental Care On line, 7(1), 145-154.

Marôco, J. (2014). Análise estatística com o SPSS statistics. Pêro Pinheiro, Portugal: Report Number.

Muela, J. A., Torres, C. J., \& Peláez, E. M. (2001). La evaluación de la asertividad como predictor de carga en cuidadores de enfermos de Alzheimer. Revista Española de Geriatria y Gerontologia, 36(1), 41-45.

Neri, A. L., Yassuda, M. S., Fortes-Burgos, A. C. G., Mantovani, E. P., Arbex, F. S., Torres, S. V. S.,
Perracini, M. R., \& Guariento, M. E. (2012). Relationships between gender, age, family conditions, physical and mental health, and social isolation of elderly caregivers. International Psychogeriatrics, 24(3), 472-483. doi: 10.1017/ S1041610211001700

Novelli, M. M. P. C. (2006). Validação da escala de qualidade de vida ( $Q d V-D A)$ para pacientes com doença de Alzheimer e seus respectivos cuidadores familiares (Doctoral dissertation, Universidade de São Paulo, SP, Brazil).

Pasquali, L. (1999). Instrumentos psicológicos: Manual prático de elaboração. Brasília, DF: Laboratório de Pesquisa e Medida, Universidade de Brasília.

Pasquali, L. (2007). Validade dos testes psicológicos: Será possível reencontrar o caminho? Psicologia: Teoria e Pesquisa, 23, 99-107.

Pasquali, L. (2015). Delineamento de pesquisa em ciência: Vol. 2. São Paulo, SP: Vetor.

Pereira, L. S. M., \& Soares, S. M. (2015). Fatores que influenciam a qualidade de vida do cuidador familiar do idoso com demência. Ciência \& Saúde Coletiva, 20(12), 3839-3851. doi: 10.1590/1413812320152012.15632014

Pinto, F. N. F. R. (2016). Construção e Análise Psicométrica de um Inventário de Habilidades Sociais para Cuidadores de Idosos Familiares (Doctoral dissertation, Universidade Federal de São Carlos, SP, Brazil).

Pinto, F. N. F. R., \& Barham, E. J. (2014). Habilidades sociais e estratégias de enfrentamento de estresse: Relação com indicadores de bemestar psicológico em cuidadores de idosos de alta dependência. Revista Brasileira de Geriatria e Gerontologia, 15(3), 525-539. doi: $10.1590 / 1809-9823.2014 .13043$

Pinto, F. N. F. R, Barham, E. J., \& Albuquerque, P. P. (2013). Idosos vítimas de violência: Fatores sociodemográficos e subsídios para futuras intervenções. Revista Estudos e Pesquisa em Psicologia. 13(3), 1159-1181.

Pinto, F. N. F. R., Barham, E. J., \& Del Prette, Z. A. P. (2016). Interpersonal conflicts among family caregivers of the elderly: The importance of social skills. Paidéia (Ribeirão Preto), 26(64), 161-170. doi:10.1590/1982-43272664201605

Pinto, F. N. F. R., \& Oliveira, D. C. (2015). Capacidade funcional e envolvimento social em ido- 
sos: Há relação? Revista Brasileira de Ciências do Envelhecimento Humano, 12(1), 56-68. doi: 10.5335/rbceh.v12i1.4687

Queluz, F. N. F. R., Barham, E. J., Del Prette, Z. A. P., Fontaine, A. M. G.V., \& Olaz, F. O. (2017). Inventário de Habilidades Sociais para Cuidadores de Idosos (IHS-CI): Evidências de validade. Avaliação Psicológica, 16(1), 78-86. doi: 10.15689/ap.2017.1601.09

Robinson, K. M. (1988). A social skills training program for adult caregivers. Advances in Nursing Science, 10(20), 59-72.

Robinson, K. M. (1990). The relationships between social skills, social support, self-esteem and burden in adult caregivers. Journal of Advanced Nursing, 15(7), 788-795.

Robinson, K. M., \& Yates, K. (1994). Effects of Two Caregiver-Training Programs on Burden and Attitude Toward Help. Archives of Psychiatric Nursing, 8(5), 312-319.

Scazufca, M. (2002). Versão brasileira da escala Burden Interview para avaliação de sobrecarga em cuidadores de indivíduos com doenças mentais. Revista Brasileira de Psiquiatria, 24(1), 12-17.

Sebern, M. D., \& Whitlatch, C. J. (2007). Dyadic relationship scale: A measure of the impact of the provision and receipt of family care. The Gerontologist, 47(6), 741-751.

Segrin, C., McNelis, M., \& Swiatkowski, P. (2016). Social Skills, Social support, and psychological distress: A test of the social skills deficit vulnera- bility model. Human Communication Research, 42(2016), 122-137. doi: 10.1111/hcre.12070

Shafer, A. B., (2006). Meta-analysis of the Factor Structures of Four Depression Questionnaires: Beck, CES-D, Hamilton, and Zung. Journal of clinical psychology, 62(1), 123-146. doi: $10.1002 /$ jclp.20213

Taub, A., Andreoli, S. B., \& Bertolucci, P. H. (2004). Dementia caregiver Burden: Reliability of the Brazilian version of the Zarit caregiver burden interview. Caderno de Saúde Pública, 20(2), 372-376.

Thomazatti, A. P. G., \& Barham, E. J. (2010). Integrando medidas qualitativas e quantitativas para avaliar a qualidade do relacionamento mãeidosa e filha-cuidadora. Paper presented at the XVII Congresso de Iniciação Científica, Universidade Federal de São Carlos, SP, Brazil.

Wang, X. R., Robinson, K. M, \& Carter-Harris, L. (2014). Prevalence of chronic illnesses and characteristics of chronically ill informal caregivers of persons with dementia. Age and Ageing, 43(1), 137-141. doi: 10.1093/ageing/aft142

Received: 3/01/2017 $1^{\text {st }}$ revision: $29 / 03 / 2017$ Accepted: 04/04/2017

(c) BY BY The Author(s), 2018. Open Access. This article is distributed under the terms of the Creative Commons Attribution 4.0 International License (http://creativecommons.org/licenses/by/4.0/), which permits unrestricted use, distribution, and reproduction in any medium, provided you give appropriate credit to the original author(s) and the source, provide a link to the Creative Commons license, and indicate if changes were made. 